\title{
Nevertheless, the importance of coagulation abnormalities should be emphasized in international sepsis guidelines
}

\author{
Toshiaki Iba ${ }^{1 *} \mathbb{D}$, Osamu Nishida², Jerrold H. Levy ${ }^{3}$ and Marcel Levi ${ }^{4,5}$
}

\begin{abstract}
It is generally accepted that a coagulation/fibrinolysis disorder is involved in the pathogenesis of sepsis, and the association of disseminated intravascular coagulation (DIC) and poor outcomes have been reported. Based on these findings, recently released "Japanese Surviving Sepsis Campaign guidelines 2020" recommend the diagnosis of DIC and the application of anticoagulants for sepsis-associated DIC. Meanwhile, the updated "International Guidelines for the Management of Sepsis and Septic Shock 2021" did not mention coagulation abnormalities or DIC. Because management strategies continue to evolve to provide improved outcomes in sepsis, the role of adjunctive anticoagulant treatment should be included in subsequent international guidelines.
\end{abstract}

Keywords: Sepsis, Coagulopathy, Disseminated intravascular coagulation, Endothelial cell, Anticoagulation

\section{Dear Editor,}

We realized that there are some discrepancies between the recently updated "Japanese Surviving Sepsis Campaign guidelines 2020" and "Surviving Sepsis Campaign International Guidelines for the Management of Sepsis and Septic Shock 2021" [1, 2]. In the Japanese guidelines, the early detection of disseminated intravascular coagulation (DIC) is emphasized and the use of certain anticoagulants for sepsis-associated DIC was weakly recommended. Meanwhile, the chapter on "anticoagulation" is eliminated from the recent version of International guidelines.

It is widely accepted that an extensive connection and cross-talk between inflammation and coagulation occurs in sepsis. Indeed, the mortality of sepsis worsens considerably when a patient develops coagulation abnormalities, in its most extreme form DIC. Although

\footnotetext{
*Correspondence: toshiiba@juntendo.ac.jp

${ }^{1}$ Department of Emergency and Disaster Medicine, Juntendo University

Graduate School of Medicine, 2-1-1 Hongo Bunkyo-ku, Tokyo 113-8421, Japan

Full list of author information is available at the end of the article
}

mechanistically different, COVID-19 taught us that coagulopathy and subsequent pulmonary and multiorgan microthrombosis are important in the pathogenesis of organ failure and death in thromboinflammatory diseases [3] as well as the occurrence of venous thromboembolism. As a reminder, coagulopathy that occurs in acute infectious processes represents acute inflammation, dysregulated immune reactions, platelet activation, and endothelial dysfunction [4]. For these reasons, anticoagulation is important for preventing thromboembolism but also microthrombosis in COVD-19 but also in sepsisinduced coagulopathy. Apart from that, antithrombotic prophylaxis is crucial to prevent thromboembolic complications in critically ill patients.

The early detection of coagulopathy is critical and Umemura et al. [5] reported the screening of DIC improved the outcome in patients with sepsis. Although no consistently reliable method is available to evaluate the coagulopathy in sepsis, the International Society on Thrombosis and Haemostasis introduced a scoring system for sepsis-induced coagulopathy (SIC), and emphasized the importance of early detection of a original author(s) and the source, provide a link to the Creative Commons licence, and indicate if changes were made. The images or other third party material in this article are included in the article's Creative Commons licence, unless indicated otherwise in a credit line to the material. If material is not included in the article's Creative Commons licence and your intended use is not permitted by statutory regulation or exceeds the permitted use, you will need to obtain permission directly from the copyright holder. To view a copy of this licence, visit http://creativecommons.org/licenses/by/4.0/. The Creative Commons Public Domain Dedication waiver (http://creativeco mmons.org/publicdomain/zero/1.0/) applies to the data made available in this article, unless otherwise stated in a credit line to the data. 
coagulation derangement [6]. SIC consists of a simple algorithm (platelet count, prothrombin time [international normalization ratio], and Sequential Organ Failure Assessment [SOFA] score) and has been validated to detect the coagulopathy in sepsis.

Although there is no proven effective treatment for coagulopathy and DIC in sepsis, Japanese Surviving Sepsis Campaign guidelines 2020 weekly recommend the use of antithrombin and recombinant thrombomodulin for DIC. Since some of the authors have a conflict of interest with the related pharmaceuticals, it may not be appropriate to discuss the effects of anticoagulation in this letter. However, it is necessary to explain that although a recent randomized controlled trial examining the effect of recombinant thrombomodulin in severe sepsis (SCARLET trial) failed to show a beneficial effect on survival in an intention-totreat population, it showed a survival benefit in patients with more severe coagulopathy [7]. Levi et al. [8] also demonstrated that patients treated with recombinant human soluble thrombomodulin having higher baseline prothrombin fragment ${ }_{1.2}$ or thrombin-antithrombin complex had lower mortality compared with patients receiving placebo in post hoc analysis. Furthermore, other anticoagulant interventions such as supplementation of antithrombin and restoration of glycocalyx have shown promising results in patients with severe sepsis and coagulopathy $[9,10]$.

We hope that in the subsequent version of the international guidelines, consideration of the role of coagulation and appropriate anticoagulant adjunctive treatment in severe sepsis will be included to underline the importance of detecting and managing coagulopathy in these critically ill patients.

\section{Abbreviations}

DIC: Disseminated intravascular coagulation; SIC: Sepsis-induced coagulopathy; SOFA: Sequential Organ Failure Assessment.

\section{Acknowledgements}

None.

\section{Authors' contributions}

$\mathrm{TI}$ and $\mathrm{JHL}$ wrote the draft. ON and ML reviewed and edited. All authors read and approved the final manuscript.

\section{Authors' information}

IT and ON are the committee members of Japanese Surviving Sepsis Campaign Guidelines 2020. LJH is a chairman of the International Society on Thrombosis and Haemostasis/Critical Care SSC.

\section{Funding}

None.

Availability of data and materials

Not applicable.

\section{Declarations}

\section{Ethics approval and consent to participate}

Not applicable.

\section{Consent for publication}

Not applicable.

\section{Competing interests}

IT has received research grants and scholarships from Japan Blood Products Organization, JIMRO, and Asahi Kasei Pharmaceuticals. NO received scholarships from Fuso Pharmaceutical Industries, Asahi Kasei Pharmaceuticals, Baxter Ltd., Maruishi Pharmaceutical, Teijin Pharmaceutical, Ono Pharmaceutical, Torii Pharmaceutical, Shionogi Co., Ltd. LJH serves on the Steering Committees for Instrumentation Laboratories, Octapharma, and Merck. LM has received grants and has participated in advisory boards of NovoNordisk, Eli Lilly, Asahi Kasei Pharmaceuticals America and Johnson \& Johnson. The other authors state that they have no conflicts of interest.

\section{Author details}

${ }^{1}$ Department of Emergency and Disaster Medicine, Juntendo University Graduate School of Medicine, 2-1-1 Hongo Bunkyo-ku, Tokyo 113-8421, Japan. ${ }^{2}$ Department of Anesthesiology and Critical Care Medicine, Fujita Health University School of Medicine, Kutsukake-Machi, Toyoake 471-11, Japan. ${ }^{3}$ Department of Anesthesiology, Critical Care, and Surgery, Duke University School of Medicine, Durham, NC, USA. ${ }^{4}$ Department of Medicine, University College London Hospitals NHS Foundation Trust, and Cardio-Metabolic ProgrammeNIHR UCLH/UCL BRC London, Tottenham Court Road, London, UK. ${ }^{5}$ Department of Vascular Medicine, Amsterdam Cardiovascular Science, Amsterdam University Medical Centers, Amsterdam, the Netherlands.

Received: 25 November 2021 Accepted: 10 January 2022

Published online: 21 January 2022

\section{References}

1. Egi M, Ogura H, Yatabe T, Atagi K, Inoue S, Iba T, Kakihana Y, Kawasaki T, Kushimoto S, Kuroda Y, Kotani J, Shime N, Taniguchi T, Tsuruta R, Doi K, Doi M, Nakada TA, Nakane M, Fujishima S, Hosokawa N, Masuda Y, Matsushima A, Matsuda N, Yamakawa K, Hara Y, Sakuraya M, Ohshimo S, Aoki Y, Inada M, Umemura Y, Kawai Y, Kondo Y, Saito H, Taito S, Takeda C, Terayama T, Tohira H, Hashimoto H, Hayashida K, Hifumi T, Hirose T, Fukuda T, Fujii T, Miura S, Yasuda H, Abe T, Andoh K, lida Y, Ishihara T, Ide K, Ito K, Ito Y, Inata Y, Utsunomiya A, Unoki T, Endo K, Ouchi A, Ozaki M, Ono S, Katsura M, Kawaguchi A, Kawamura Y, Kudo D, Kubo K, Kurahashi K, Sakuramoto H, Shimoyama A, Suzuki T, Sekine S, Sekino M, Takahashi N, Takahashi S, Takahashi H, Tagami T, Tajima G, Tatsumi H, Tani M, Tsuchiya A, Tsutsumi Y, Naito T, Nagae M, Nagasawa I, Nakamura K, Nishimura T, Nunomiya S, Norisue Y, Hashimoto S, Hasegawa D, Hatakeyama J, Hara N, Higashibeppu N, Furushima N, Furusono H, Matsuishi Y, Matsuyama T, Minematsu Y, Miyashita R, Miyatake Y, Moriyasu M, Yamada T, Yamada $H$, Yamamoto R, Yoshida T, Yoshida Y, Yoshimura J, Yotsumoto R, Yonekura H, Wada T, Watanabe E, Aoki M, Asai H, Abe T, Igarashi Y, Iguchi N, Ishikawa M, Ishimaru G, Isokawa S, Itakura R, Imahase H, Imura H, Irinoda T, Uehara K, Ushio N, Umegaki T, Egawa Y, Enomoto Y, Ota K, Ohchi Y, Ohno T, Ohbe H, Oka K, Okada N, Okada Y, Okano H, Okamoto J, Okuda H, Ogura T, Onodera Y, Oyama Y, Kainuma M, Kako E, Kashiura M, Kato H, Kanaya A, Kaneko T, Kanehata K, Kano Kl, Kawano H, Kikutani K, Kikuchi H, Kido T, Kimura S, Koami H, Kobashi D, Saiki I, Sakai M, Sakamoto A, Sato T, Shiga Y, Shimoto M, Shimoyama S, Shoko T, Sugawara Y, Sugita A, Suzuki S, Suzuki Y, Suhara T, Sonota K, Takauji S, Takashima K, Takahashi S, Takahashi Y, Takeshita J, Tanaka Y, Tampo A, Tsunoyama T, Tetsuhara K, Tokunaga K, Tomioka Y, Tomita K, Tominaga N, Toyosaki M, Toyoda Y, Naito H, Nagata I, Nagato T, Nakamura Y, Nakamori Y, Nahara I, Naraba H, Narita C, Nishioka N, Nishimura T, Nishiyama K, Nomura T, Haga T, Hagiwara Y, Hashimoto K, Hatachi T, Hamasaki T, Hayashi T, Hayashi M, Hayamizu A, Haraguchi G, Hirano Y, Fujii R, Fujita M, Fujimura N, Funakoshi H, Horiguchi M, Maki J, Masunaga N, Matsumura Y, Mayumi T, Minami K, Miyazaki Y, Miyamoto K, Murata T, Yanai M, Yano T, Yamada K, Yamada N, Yamamoto T, Yoshihiro S, 
Tanaka H, Nishida O. The Japanese clinical practice guidelines for management of sepsis and septic shock 2020 (J-SSCG 2020). J Intensive Care. 2021;9:53.

2. Evans L, Rhodes A, Alhazzani W, Antonelli M, Coopersmith CM, French C, Machado FR, Mcintyre L, Ostermann M, Prescott HC, Schorr C, Simpson S, Wiersinga WJ, Alshamsi F, Angus DC, Arabi Y, Azevedo L, Beale R, Beilman G, Belley-Cote E, Burry L, Cecconi M, Centofanti J, Coz Yataco A, De Waele J, Dellinger RP, Doi K, Du B, Estenssoro E, Ferrer R, Gomersall C, Hodgson C, Møller MH, Iwashyna T, Jacob S, Kleinpell R, Klompas M, Koh Y, Kumar A, Kwizera A, Lobo S, Masur H, McGloughlin S, Mehta S, Mehta Y, Mer M, Nunnally M, Oczkowski S, Osborn T, Papathanassoglou E, Perner A, Puskarich M, Roberts J, Schweickert W, Seckel M, Sevransky J, Sprung CL, Welte T, Zimmerman J, Levy M. Surviving sepsis campaign: international guidelines for the management of sepsis and septic shock 2021. Intensive Care Med. 2021;2:1-67.

3. Levi M, Thachil J, Iba T, Levy JH. Coagulation abnormalities and thrombosis in patients with COVID-19. Lancet Haematol. 2020;7:e438-40.

4. Iba T, Levy JH. Inflammation and thrombosis: roles of neutrophils, platelets and endothelial cells and their interactions in thrombus formation during sepsis. JThromb Haemost. 2018;16:231-41.

5. Umemura Y, Yamakawa K, Hayakawa M, Hamasaki T, Fujimi S, Japan Septic Disseminated Intravascular Coagulation (J-Septic DIC) study group. Screening itself for disseminated intravascular coagulation may reduce mortality in sepsis: a nationwide multicenter registry in Japan. Thromb Res. 2018;161:60-6.

6. Iba T, Levy JH, Warkentin TE, Thachil J, van der Poll T, Levi M. Diagnosis and management of sepsis-induced coagulopathy and disseminated intravascular coagulation. J Thromb Haemost. 2019;17:1989-94.

7. Vincent JL, Francois B, Zabolotskikh I, Daga MK, Lascarrou JB, Kirov MY, Pettilä V, Wittebole X, Meziani F, Mercier E, Lobo SM, Barie PS, Crowther M, Esmon CT, Fareed J, Gando S, Gorelick KJ, Levi M, Mira JP, Opal SM, Parrillo J, Russell JA, Saito H, Tsuruta K, Sakai T, Fineberg D. Effect of a recombinant human soluble thrombomodulin on mortality in patients with sepsis-associated coagulopathy: the SCARLET randomized clinical trial. JAMA. 2019;321:1993-2002.

8. Levi M, Vincent JL, Tanaka K, Radford AH, Kayanoki T, Fineberg DA, Hoppensteadt D, Fareed J. Effect of a recombinant human soluble thrombomodulin on baseline coagulation biomarker levels and mortality outcome in patients with sepsis-associated coagulopathy. Crit Care Med. 2020:48(8):1140-7.

9. Iba T, Levi M, Levy JH. Sepsis-induced coagulopathy and disseminated intravascular coagulation. Semin Thromb Hemost. 2020;46(1):89-95.

10. Uchimido R, Schmidt EP, Shapiro NI. The glycocalyx: a novel diagnostic and therapeutic target in sepsis. Crit Care. 2019;23(1):16.

\section{Publisher's Note}

Springer Nature remains neutral with regard to jurisdictional claims in published maps and institutional affiliations.

Ready to submit your research? Choose BMC and benefit from:

- fast, convenient online submission

- thorough peer review by experienced researchers in your field

- rapid publication on acceptance

- support for research data, including large and complex data types

- gold Open Access which fosters wider collaboration and increased citations

- maximum visibility for your research: over $100 \mathrm{M}$ website views per year

At BMC, research is always in progress.

Learn more biomedcentral.com/submissions 